
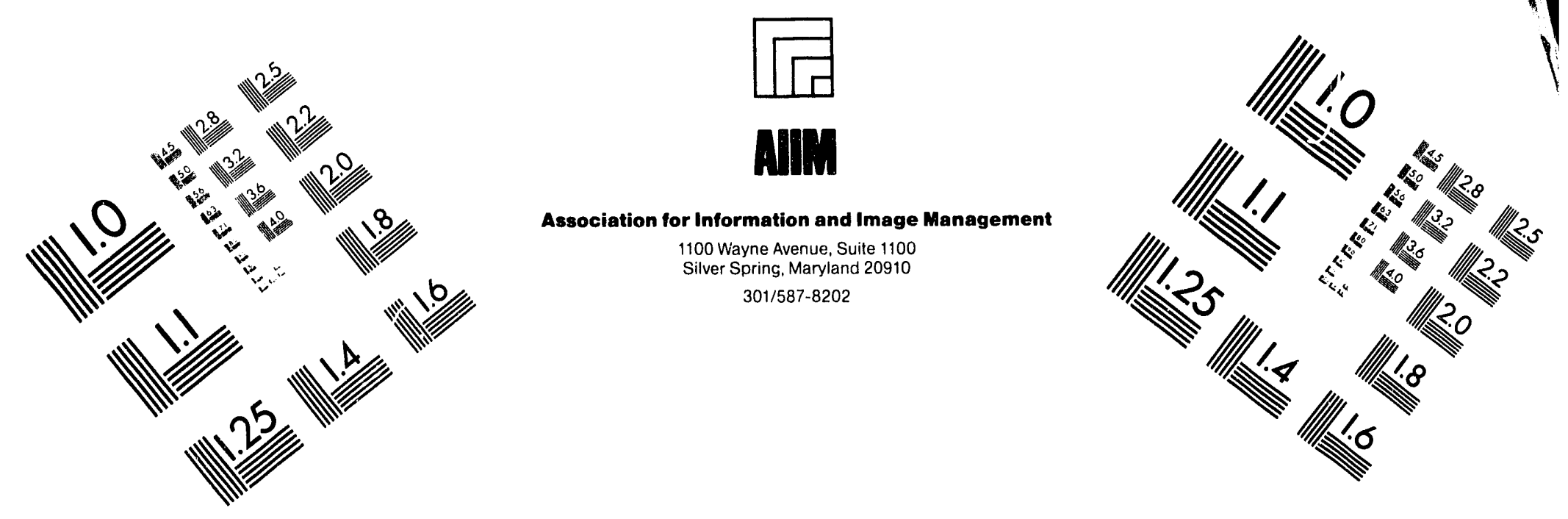

\title{
Centimeter
}

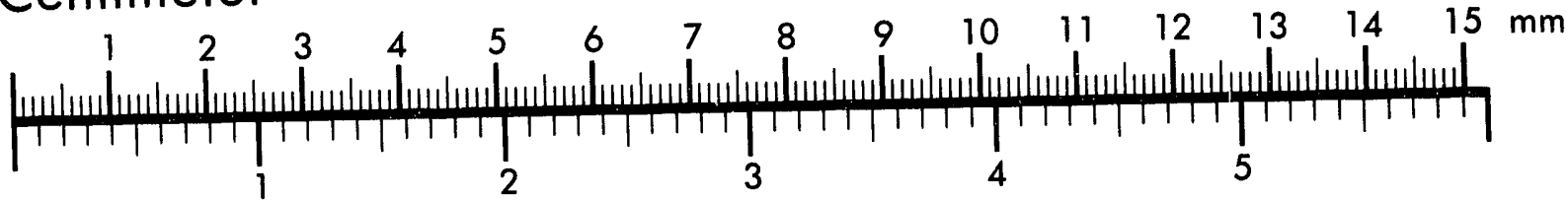
Inches
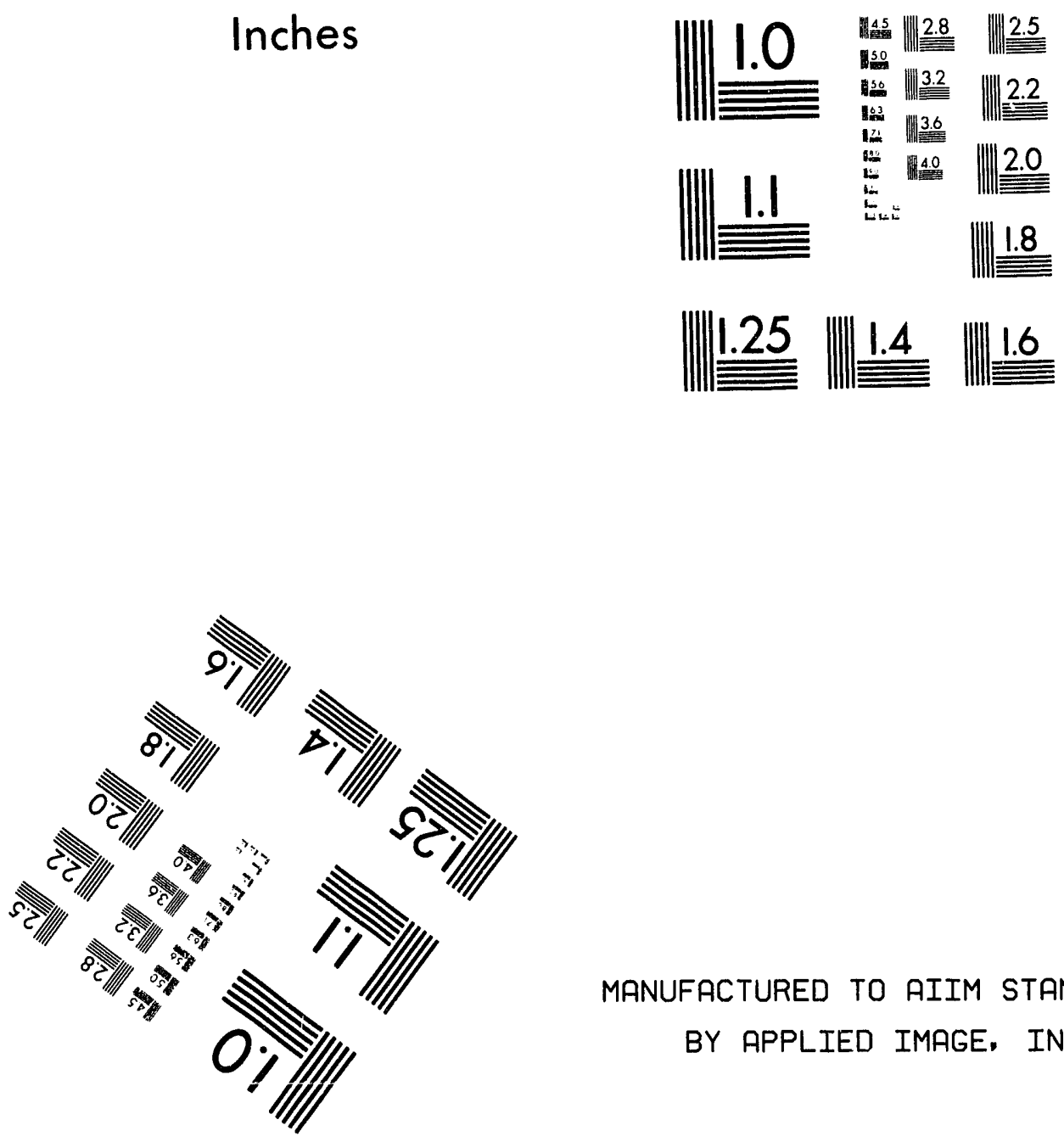

MANUFACTURED TO AIIM STANDARDS

BY APPLIED IMAGE, INC.

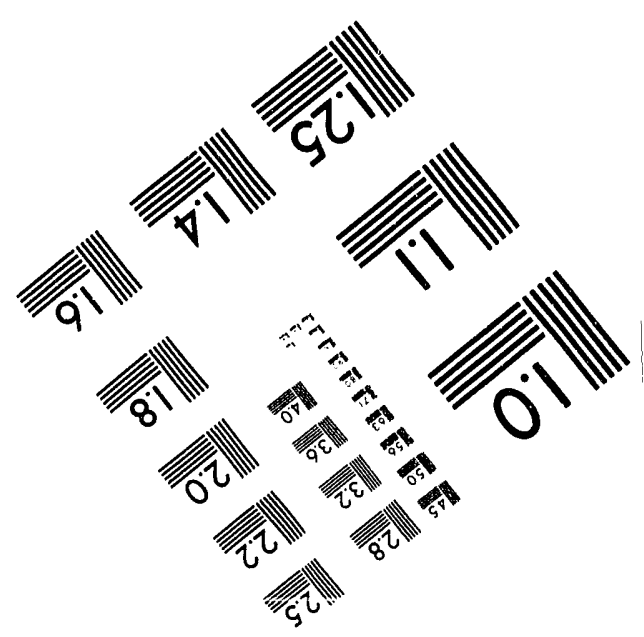



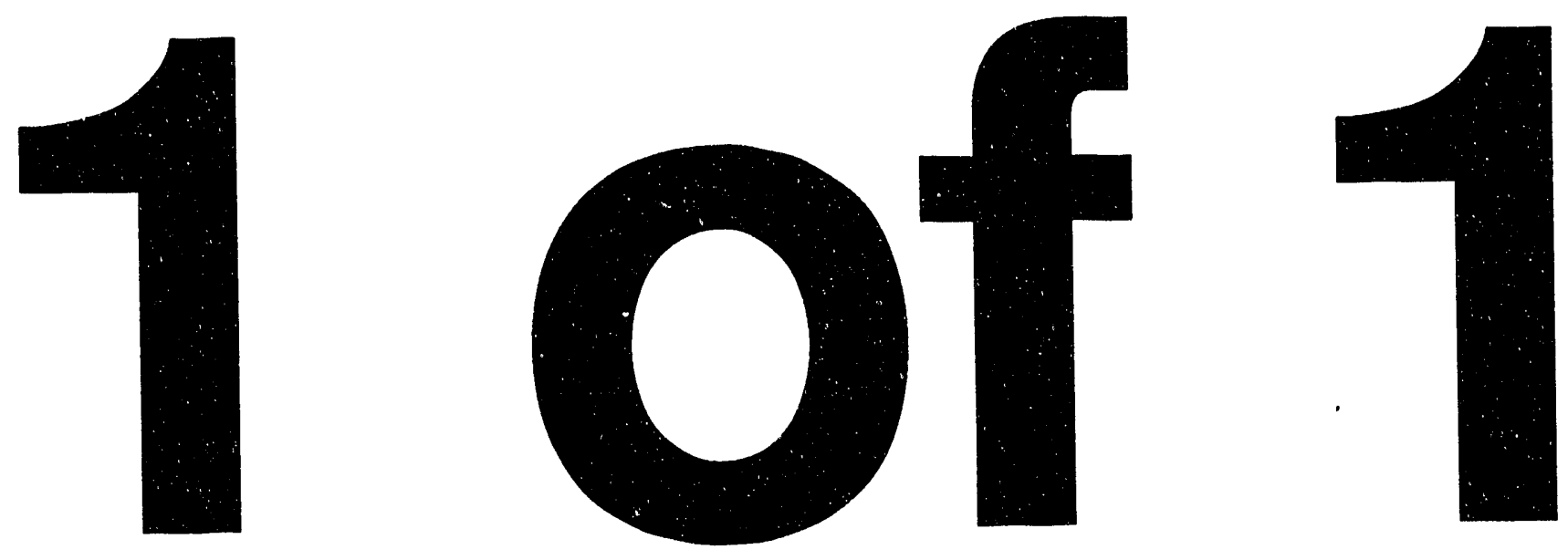


\title{
PALSA-OOSOI
}

\section{Epidermal Growth Factor Receptor Expression in Radiation-Induced Dog Lung Tumors by Immunocytochemical Localization}

\author{
F. L. Leung, 1, 2 J. F. Park, and G. E. Dagle
}

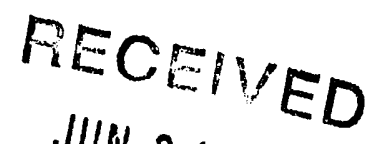

JUH $\rightarrow 1933$

os r,

\author{
Biology and Chemistry Department \\ Pacific Northwest Laboratory \\ P.O. Box 999, K4-13 \\ Richland, WA
}

\section{DISCLAIMER}

as an account of work sponsored by an agency of the United States Governent, nor any of their Government. Neither the United States Government or assumes any legal liability or responsiemployees, makes any warranty, express or implied, of assu information, apparatus, product, or bility for the accuracy, completeness, or usefulness of any inge privately owned rights. Referprocess disclosed, or represents that its use would not is or service by trade name, trademark, ence herein to any specific commercial product, process, or service bly its endorsement, recommanufacturer, or otherwise does not necessarily constitute or imply igency thereof. The views mendation, or favoring by the United States Government or any ate or reflect those of the

mendation, or favinions of authors expressed herein do not
United States Government or any agency thereof.

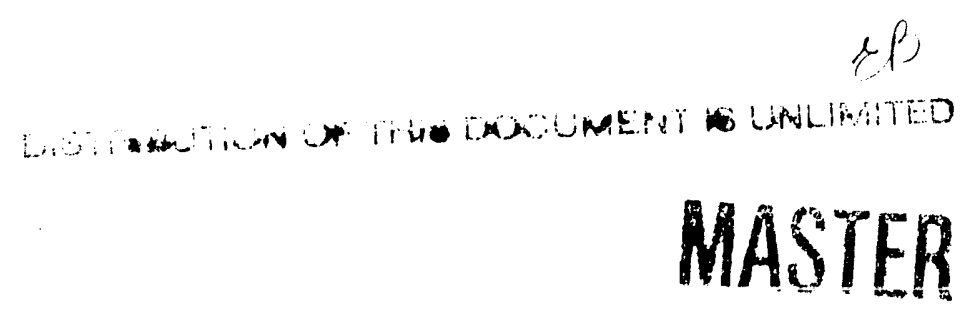


1 Work was supported by the Office of Energy Research, U.S. Department of Energy, under contract DE-AC06-76RLO 1830.

2 Address all correspondence and reprint requests to:

Fred C. Leung, MS K4-13

Biology and Chemistry Department

Pacific Northwest Laboratory

P. O. Box 999

Richland, WA 99352

(509) $375-2169$

FAX: (509) 375-6891 
Epidermal Growth Factor Receptor -apression in Radiation-Induced Dog Lung Tumors by Immunocytochemical Localization

F. L. Leung, ${ }^{1,} 2$ J. F. Park, and G. E. Dagle

Biology and Chemistry Department, Pacific Northwest Laboratory, P.O. Box 999, K4-13, Richland, Washington 9935 ?

\section{ABSTRACT}

In studies to determine the role of growth factors in radiationinduced lung cancer, epidermal growth factor (EGFR) expression was examined by immunocytochemistry in 51 lung tumors from beagle dogs exposed to inhaled plutonium; 21 of $51(41 \%)$ tumors were positive for EGFR. The fraction of tumors positive for EGFR an's the histological type of EGFR-positive tumors in the plutoniumexposed dogs were not different from spontaneous dog lung tumors, in which $36 \%$ were positive for EGFR. EGFR involvement in Pu-induced lung tumors appeared to be similar to that in spontaneous lung tumors. However, EGFR-positive staining was observed in only 1 of 16 tumors at the three lowest Pu exposure levels, compared to 20 of 35 tumors staining positive at the two highest $\mathrm{Pu}$ exposure levels. The results in dogs were in good agreement with the expression of EGFR reported in human nonsmall cell carcinoma of the lung, suggesting that Pu-induced lung tumors in the dog may be a suitable animal model to investigate the role of EGFR expression in lung carcinogenesis. In humans, EGFR expression in lung tumors has been primarily related to histological tumor types. In individual dogs with multiple primary lung tumors, the tumors were either all EGFR positive or EGFR negative, suggesting that EGFR expression may be related to the response of the individual dog as well as to the histological type of tumor. 


\section{INTRODUCTION}

Epidermal growth factor (EGF) is a small polypeptide (53 amino acids) with a molecular weight of 6,045 that was first isolated from mouse salivary glands (1) and subsequently shown to be present in a variety of tissues $(2,3)$. The regulation of cellular growth and proliferation by EGF is mediated by the bincing of EGF to a specific membrane glycoprotein receptor with a molecular weight of 170,000 (4). This EGF receptor (EGFR) consists of an extracellular ligandbinding domain, a transmembrane portion, and an intracellular domain with tyrosine kinase activity $(4,5)$. The EGFR also phosphorylates a number of protein substrates in addition to mediating autophosphorylation of tyrosine residues located near the carboxyl terminal (6).

The role of EGF and its receptor in normal and disease states is under active investigation, but the mechanisms are poorly understood. EGF has been shown to increase cell growth by increased DNA synthesis and to be involved in cell proliferation, differentiation, wound healing in epithelial tissue, and oncogenesis (7-9). The EGFR gene shares a highly significant degree of homology with the erb-B family of oncogenes, and the v-erb-B oncogene derived from a strain of avian erythroblastosis virus encodes a transforming protein with homology to a truncated form of EGFR that lacks the extracellular ligand-binding domain (7-10). EGFR is overexpressed in various malignant tumors and appears to play an important role in the pathogenesis of these carcinomas. In human lung cancer, increased EGFR has been demonstrated using radioreceptor binding and immunocytochemical assays (11-13). The overexpression of EGFR is mainly associated with non-small cell carcinoma of the lung (NSCCL), particularly with epidermoid carcinomas (14-16).

In studies to determine the role of growth factors in radiation-induced lung cancer, we recently reported increased EGFR expression in plutonium-induced dog lung tumors by radioreceptor binding assay (17). In this report, we further examine the expression of EGFR in plutonium-induced dog lung tumors using an immunocytochemical assay. 


\section{MATERIALS AND METHODS}

Formalin-fixed, paraffin-embedded dog lung tumor samples were obtained from our ongoing long-term experiments to determine the life-span dose-effect relationships of inhaled plutonium (18). Beagle dogs were exposed to either inhaled $239 \mathrm{PuO}_{2}, 238 \mathrm{PuO}_{2}$, or $239 \mathrm{Pu}\left(\mathrm{NO}_{3}\right)_{4}$ (Table 1). A total of 51 randomly selected primary lung tumors were obtained from Pu-exposed dogs and compared with 6 primary lung tumors from control dogs; a total of 6 lung tumors were observed in the control dogs. In the lung tumors from exposed dogs, 1 was from dose-level group 1, 5 were from dose-level group 2, 10 from doselevel group 3, 27 from dose-level group 4, and 8 were from dose-level group 5. Histopathological diagnosis followed the W.H.O. classification system (19).

Standard immunocytochemical staining procedure using the avidin-biotin complex (ABC) immunoperoxidase method as described by Hsu et al. (20) was used. Reagents for the staining procedure were obtained from Vector Laboratories (Burlingame, CA). A monoclonal antibody (29.1) against EGFR trom human-derived A431 cell membrane was purchased from Sigma (St. Louis, MO). The development and characterization of 29.1 have been described. Most recently, Stoscheck (2) reported that 29.1 also has a high affinity for dog EGFR.

Briefly, 5- $\mu \mathrm{m}$ paraffin sections were deparaffinized and trypsin treated before immunostaining. Intrinsic peroxidase was blocked by incubation with $\mathrm{H}_{2} \mathrm{O}_{2}$ for $30 \mathrm{~min}$. Nonspecific binding was determined by treatment with normal horse serum for $20 \mathrm{~min}$. The primary antibody, EGFR 29.1 ascites, was applied for $1 \mathrm{~h}$ at room temperature at a dilution of $1: 50$, approximately $1.0 \mu \mathrm{g} / \mathrm{ml}$. The biotinylated horse-antimouse antibody and the avidin-biotin-peroxidase complex were applied for $30 \mathrm{~min}$ each. Tissue sections were washed with Tris buffer after each reagent step. Peroxidase activity was developed with $10 \mathrm{mg}$ diaminobenzidine in Tris buffer containing $0.03 \% \mathrm{H}_{2} \mathrm{O}_{2}$. The slides were counterstained with hematoxylin and examined by light microscopy. For negative controls, normal serum was substituted for the primary antiserum. Tumor cells were graded as either positive or negative. 


\section{RESULTS}

The results of anti-EGFR monoclonal antibody staining with lung tumors from control and Pu-exposed dogs are shown in Table 1. Four of $6(67 \%)$ control dog lung tumors stained positively for EGFR whereas 21 of $51(41 \%)$ of the Puexposed dog lung tumors stained positively. In the Pu-exposed dog lung tumors, EGFR-positive staining was observed in 2 of 5 epidermoid carcinomas, 11 of 19 bronchioloalveolar carcinomas, 5 of 15 papillary adenocarcinomas, and 3 of 11 adenosquamous carcinomas. In the control dog lung tumors, EGFR staining was positive in 2 of 2 bronchioloalveolar carcinomas, 2 of 3 adenocarcinomas, and 0 of 1 adenosquamous carcinoma.

EGFR expression was not specific for the tumors in Pu-exposed dogs as compared to controls; both exposed and control dogs had EGFR-positive and FGFR-negative tumors. However, fewer EGFR-positive tumors were seen among dose groups 1 through $3(0 / 1,1 / 5$, and $0 / 10$, respectively) as compared to dose groups 4 and 5 (16/27 and 4/8, respectively).

In most of the Pu-exposed dog lung tumors (16/21, 76\%), staining was heterogeneous and patchy; in a few tumors $(5 / 21,24 \%)$, however, staining was homogeneous. Most positive-staining tumor cells displayed moderate to strong staining intensity. Examples of anti-EGFR monoclonal antibody staining of control and exposed dog lung tumors are shown in Fig. 1. There were no obvious differences in the characteristics of 29.1 staining among EGFR-positive lung tumors on the basis of histopathological classification. In addition, there were no apparent morphological differences between EGFR-positive and EGFR-negative lung tumor cells. We have observed that anti-EGFR monoclonal antibody also stained normal bronchial epithelium identified within lung tumor sections in 1 of 4 EGFR-positive control dog lung tumors and 16 of 21 EGFRpositive Pu-exposed dog lung tumors.

Of the 57 lung tumors, 28 occurred in 11 dogs with multiple primary lung tumors and 29 occurred in dogs with single lung tumors. A dog was considered to have multiple primary tumors when discrete tumors occurred in separate lung lobes in the same dog. However, some of these tumors could have been metastatic from other lobes. Table 2 lists the 11 dogs with multiple lung tumors. 
If a tumor in an individual dog was EGFR positive, all the tumors in that dog. were positive; if a tumor was EGFR negative, all the tumors in that dog were negative. Five dogs had multiple EGFR-positive tumors and 6 had multiple EGFR-negative tumors; 14 of $28(50 \%)$ tumors in these dogs were EGFR positive. In the 29 dogs with single lung tumors, $11(38 \%)$ of the tumors were EGFR positive. Of the 40 dogs with lung tumors, $16(40 \%)$ were EGFR positive.

Because the EGFR expression seemed to be similar in multiple lung tumors from the same dog, we also examined EGFR expression in littermates with lung tumors. Table 3 lists the litters with more than one dog with lung tumors. In 10 of 11 litters, all the siblings were either EGFR positive (4 litters) or negative.(6 litters). In litter number 108, two dogs were EGFR positive and one was negative.

\section{DISCUSSION}

This study on the immunocytochemical localization of EGFR in lung tumurs of dogs extends our earlier observations of elevated EGFR determined by radioreceptor binding assay (17). The radioreceptor binding assay demonstrated an increizse in EGFR in Pu-induced dog lung tumors as great as 10 fold as compared to that found in normal lung tissue. The immunocytochemical procedure, although it does not provide the quantitative data obtained with radioreceptor binding assays, identified specific histological types associated with EGFR expression. Immunocytochemistry may lack sensitivity in detecting low concentrations of antigen. The results reported here reflect an increased concentration of EGFR above normal lung levels, as shown by our procedure. However, it is possible that EGFR-negative tumors may still have higher EGFR than normal lung as determined by this procedure.

We used a commercial monoclonal antibody that is generated against a human cervical cancer cell line (A431) membrane (4) in our study because dog 
EGF and EGFR have not been purified and characterized. This monoclonal antibody has recently been demonstrated to have a strong reactivity to dog liver EGF receptor (21). Ideally, however, purified dog EGFR should be used for sequence analysis and for use as ligand and reagent for generating antibodies, and to clone the EGFR genumic gene and CDNA for sequence analysis and its comparison to the human sequence.

Because only five control beagle dogs with six lung tumors were available from these experiments, we have examined EGFR expression, using the procedures described in METHODS, in 41 spontaneous dog lung tumors collected from the University of Illinois, College of Veterinary Medicine, Small Animal Clinic (Leung et al., unpublished observations). Table 4 shows the data from the spontaneous tumors combined with the experimental controls as compared to the tumors from Pu-exposed dogs. Of the Pu-exposed dog lung tumors, $41 \%$ were EGFR positive, compared to $36 \%$ in the combined controls. The fraction of tumors positive for EGFR and the major histological types of EGFR-positive tumors in the Pu-exposed dogs were not significantly different from the combined control dogs.

Fewer EGFR-positive lung tumors occurred among Pu-exposed dose-level groups 1 through 3 ( 1 positive of 16 examined) as compared to dose-level groups 4 and 5 (20 positive of 35 examined) (see Table 1). In dose-level groups 1 through 3,1 of 11 dogs was positive as compared to 12 of 24 positive in dose-level groups 4 and 5 . The number of EGFR-positive tumors in doselevel groups 1 through 3 was less than in dose-level groups 4 and 5 for each major histological type. There was no apparent reason for this difference in EGFR staining among dose-level groups.

Our results are in general agreement with the expression of EGFR observed in human non-small cell carcinoma of the lung (NSCCL). The histological phenotypes represented in the dogs are similar to the human classification of NSCCL. In humans, a significant fraction of NSCCL overexpress $\operatorname{EGFR~}(15,16$, 22); the fraction of EGFR-positive lung epidermoid tumors in humans ranged trom $62 \%$ to $100 \%$, compared to $33 \%$ in all the dogs. In humans, EGFR-positive lung adenocarcinomas ranged from $34 \%$ to $75 \%$ compared to $45 \%$ (bronchioloalveolar plus adenocarcinoma) in all the dogs. In both humans and 
dogs, positive and negative EGFR staining was observed in each histological phenotype. The similarity of the results in dog lung tumors to the findings in human lung tumors suggests that Pu-induced dog lung tumors may be a suitable model to investigate the role of EGFR expression in lung carcinogenesis. EGFR involvement in Pu-induced lung tumors appears to be similar to that in spontaneous lung tumors.

The EGFR-positive or EGFR-negative staining characteristics of tumors may reflect variations in differentiation status. However, there was no obvious difference in the staining characteristics among EGFR-positive lung tumor types or in the morphology between EGFR-positive and EGFR-negative tumors. Most of the dogs were euthanized because of lung tumors, so these tumors represent terminal tumor stages.

Most reports of human NSCCL have shown EGFR-positive and EGFRnegative staining in each histological type. In the dogs, four observations suggested that positive EGFR expression in the lung tumors, as determined by immunocytochemistry, may be related to the response of the individual dog as well as to the histological tumor type: (1) Some tumors were negative and some positive for EGFR in all major tumor types; (2) in EGFR-positive tumor types, there was a tendency to positive EGFR staining in adjacent normal lung tissue that was not observed with EGFR-negative tumors; (3) tumors in individual dogs with multiple primary tumors of either the same or different histological types were either all EGFR positive or all EGFR negative; and (4) littermates tended to have either all EGFR-positive- or all EGFR-negativestaining tumors. If EGFR-positive or EGFR-negative staining in tumors is related to the individual, this might explair why most reported human NSCCL have both EGFR-positive and EGFR-negative histological types. 


\section{REFERENCES}

1. Cohen, S. Isolation of a mouse submaxillary gland protein accelerating incisor eruption eyelid opening in the newborn animal. J. Biol. Chem., 237: 1555-1562, 1962.

2. Rall, L.B., Scott, J., and Bell, G.I. Mouse prepro-epidermal growth factor synthesis by the kidney and other tissues. Nature (Lond.), 313: 228-231, 1985.

3. Elder, J.B., et al. Cellular localization of human urogastrone/epidermal growth factor. Nature (Lond.), 271: 464-467, 1978.

4. Cohen, S.A., et al. A native 170,000 epidermal growth factor receptorkinase complex from shed membrane vesicles. J. Biol. Chem., 257: 1523-1531, 1982.

5. Carpenter, G. and Zendegui, J.G. Epidermal growth factor, its receptor, and related proteins. Exp. Cell Res., 164:1-10, 1986.

6. Downward, J., Parker, P., and Waterfield, M. D. Autophosphorylation sites on the epidermal growth factor receptor. Nature (Lond.), 311: 483-485, 1984.

7. Carpenter, $G$. Receptors for epidermal growth factor and other polypeptide mitogens. Annu. Rev. Biochem., 56:881-914, 1987.

8. Goustin, A.S., et al. Growth factors and cancer. Cancer Res., 46:1015$1029,1986$.

9. Stoscheck, C.M., and King, L.E., Jr. Role of epidermal growth factor in carcinogenesis. Cancer Res., 46: 1030-1037, 1986.

10. Downward, J., et al. Close similarity of epidermal growth factor receptor and v-erb-B oncogene protein sequences. Nature (Lond.), 307: 521-527, 1984.

11. Hwang, D.L., et al. Expression of epidermal growth factor receptors in human lung tumors. Cancer (Phila.), 58: 2260-2263, 1986.

12. Haeder, M., et al. Epidermal growth factor receptor expression in human lung cancer cell lines. Cancer Res., 48: 1132-1136, 1988. 
13. Veale, D., et al. Epidermal growth factor receptors in non-small cell lung cancer. Br. J. Cancer, 55: 513-516, 1987.

14. Veale, D., et al. Characterization of epidermal growth factor receptor in primary human non-small cell lung cancer. Cancer Res., 49: 1313-1317, 1989.

15. Sobol, R.E., et al. Epidermal growth factor receptor expression in human lung carcinomas defined by a monoclonal antibody. J. Natl. Cancer Inst., 79: 403-407, 1987.

16. Berger, M.S., et al. Epidermal growth factor receptors in lung tumours. J. Pathol., 152: 297-307, 1987.

17. Leung, F.C., Bohn, L.R., and Dagle, G.E. Elevated epidermal growth factor (EGF) receptor binding in plutonium-induced lung tumors from dogs. Proc. Soc. Exp. Biol. Med., 196:385-389, 1991.

18. Park, J. F., et al. Current status of life-span studies with inhaled plutonium in beagles at Pacific Northwest Laboratory. In: Life-Span Radiation Effects Studies in Animals: What Can They Tell Us?, Thompson, R.C., and Mahaffey, J.A. (eds.). Springfield, VA: NTIS, pp. 455-471, 1986.

19. Stunz, H., Head, K.W., and Nielisun, S.W. Tumors of the lung. Bull. W.H.O., 50:9-19, 1974.

20. Hsu, S.M., Raine, L., and Fanger, H. Use of avidin-biotin-peroxidase complex $(A B C)$ in immunoperoxidase technique: a comparison between $A B C$ and unlabeled antibody (PAP) procedures. J. Histochem. Cytochem., 29:577$580,1981$.

21. Stoscheck, C.M. Enzyme-linked immunosorbent assay for the epidermal growth factor receptor. J. Cell. Biochem., 43:229-241, 1990.

22. Cerny, T., et al. Expression of epidermal growth factor receptor (EGF-R) in human lung tumours. Br. J. Cancer, 54:265-269, 1986. 
Figure Legend

Fig. 1. A, Epidermoid carcinoma immunostained with anti-epidermal growth factor receptor (anti-EGFR) shows intense homogeneous immunoreactivity. $B$, Papiliary adenocarcinoma immunostained with anti-EGFR. Most tumor cells stained positively; note few negative-staining cells. C, Bronchioloalveolar carcinoma immunostained with anti-EGFR. Most cells immunostained distinctly although variably. $D$, Epidermoid carcinoma immunostained with anti-EGFR. Note variable staining. 


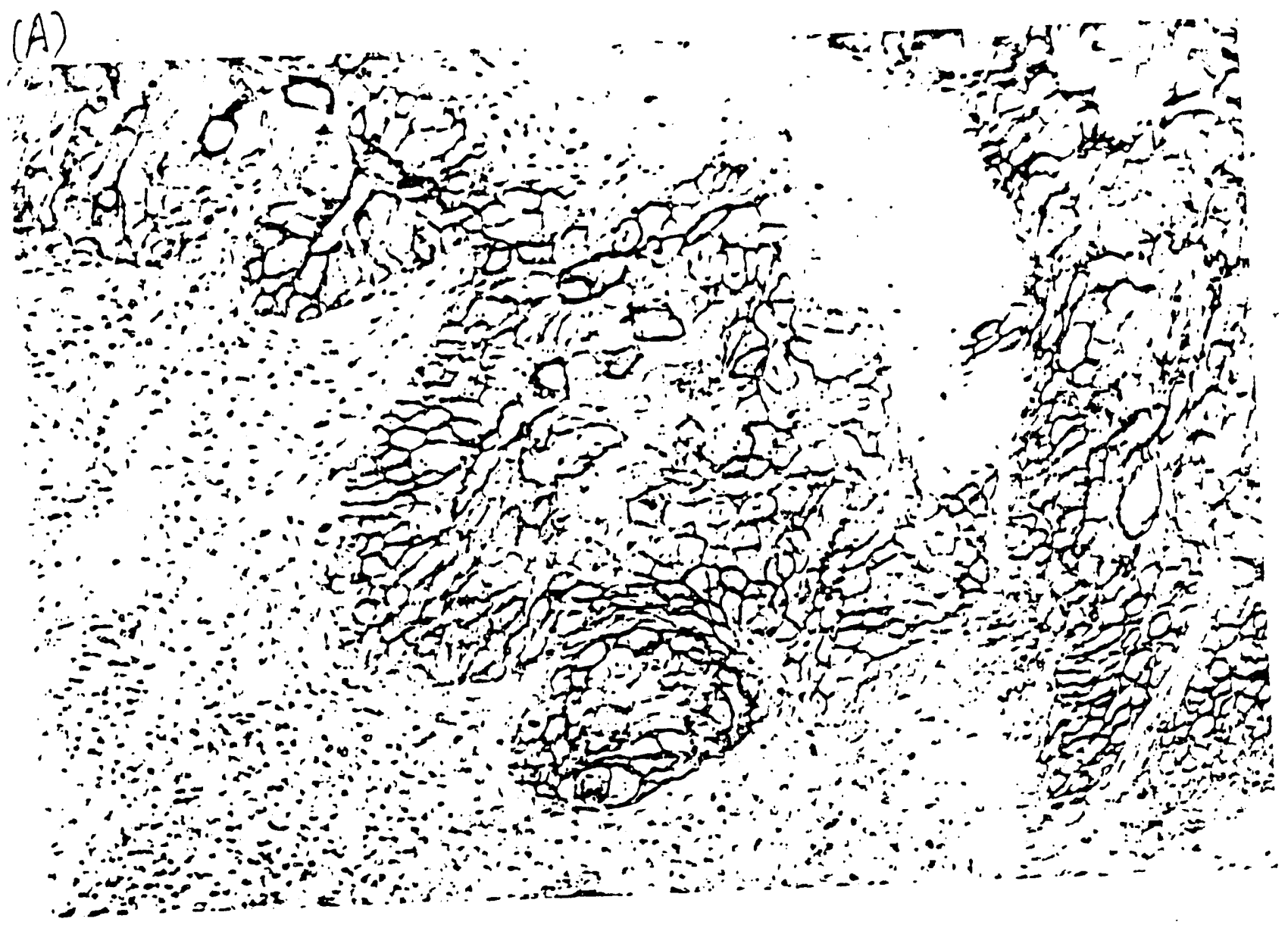
(B)

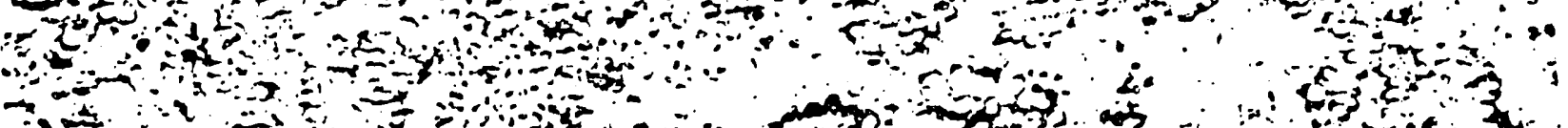
1 3 of on

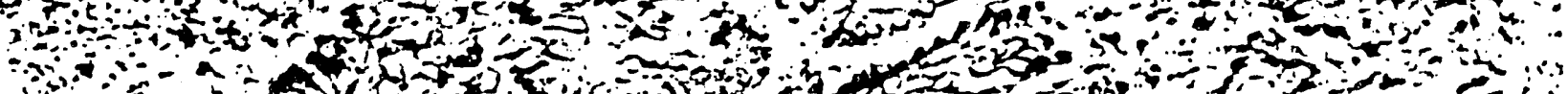

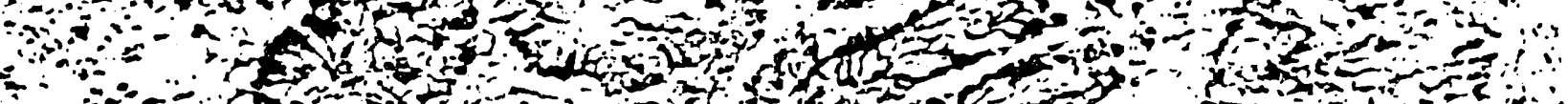

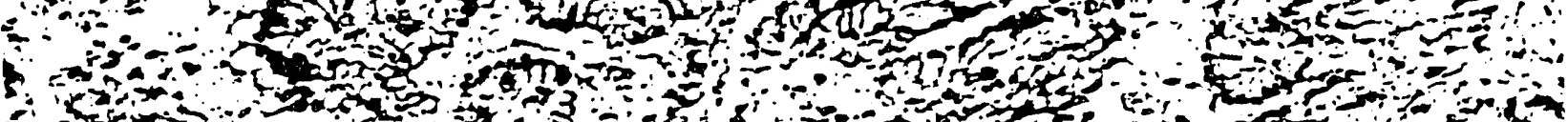
50 and

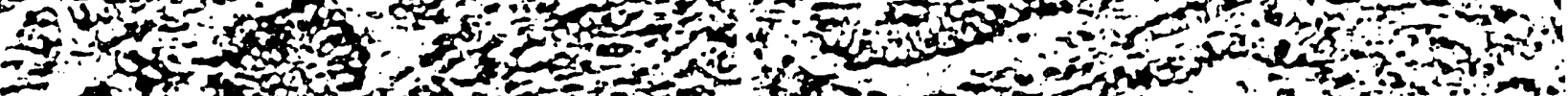
I

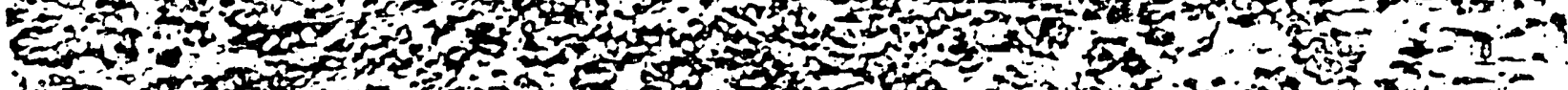

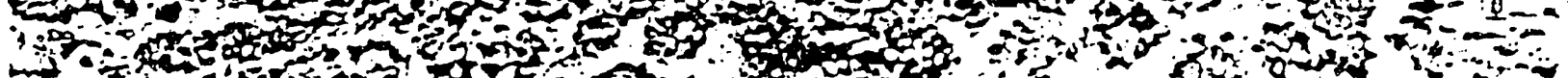
1.4. $\alpha=0$ and (5) and 
(c)

4i

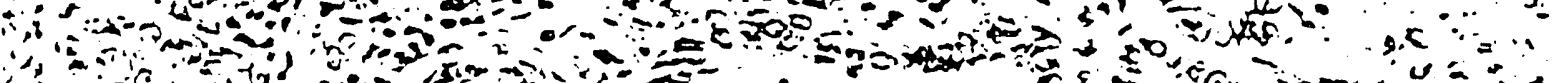

An

3.

30 (5) or

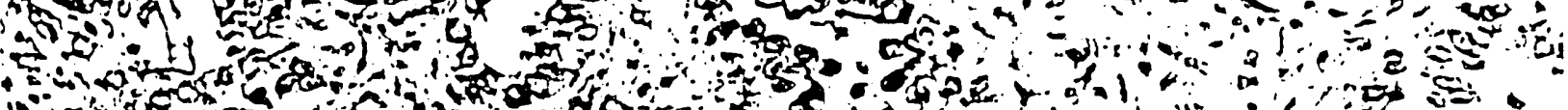

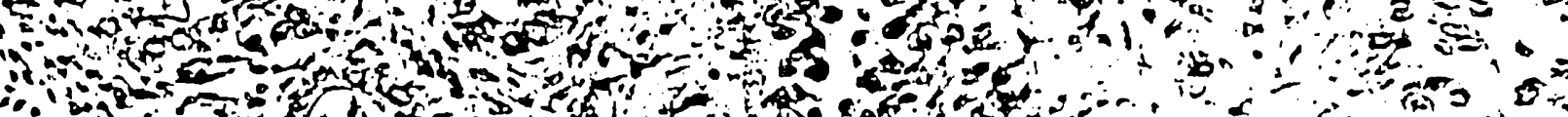
作

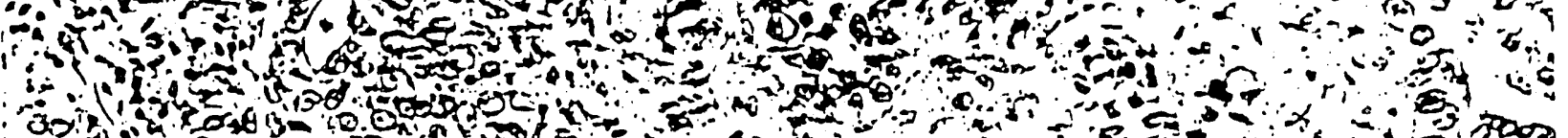

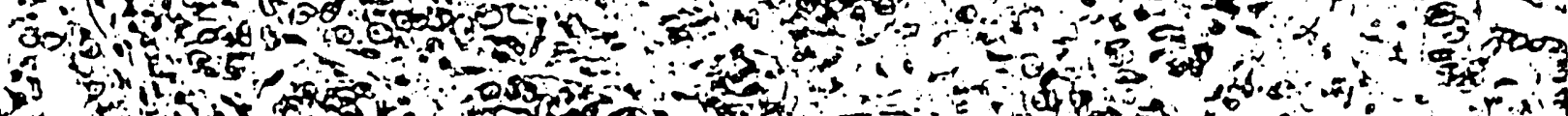

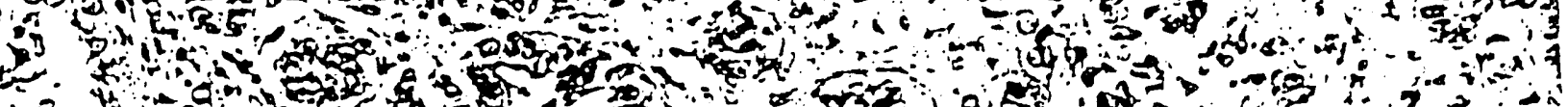

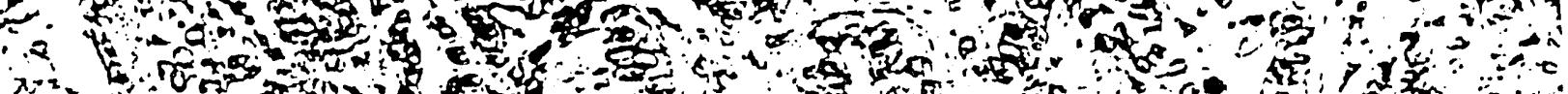

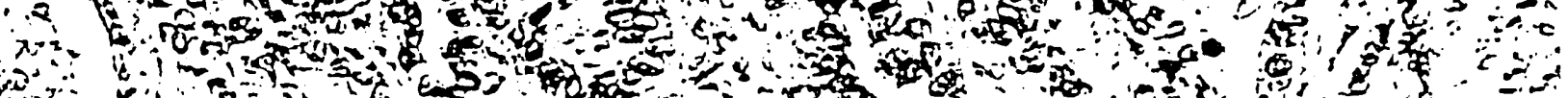

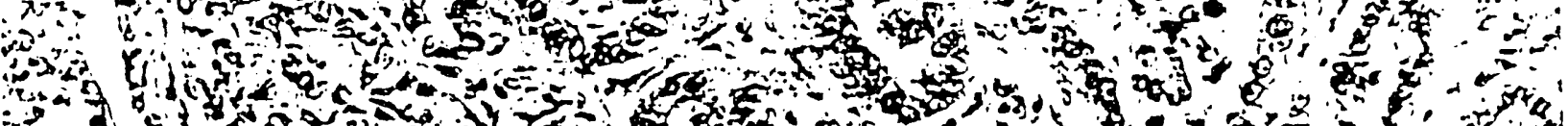

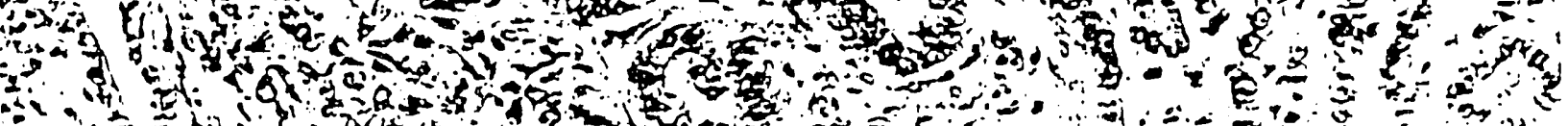

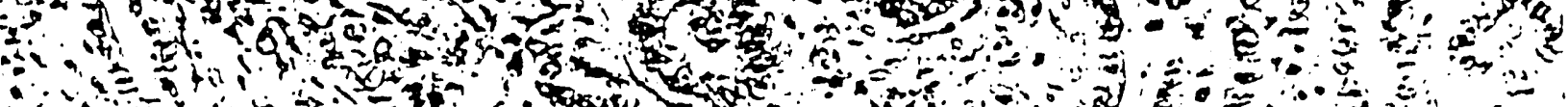
U.

(D)

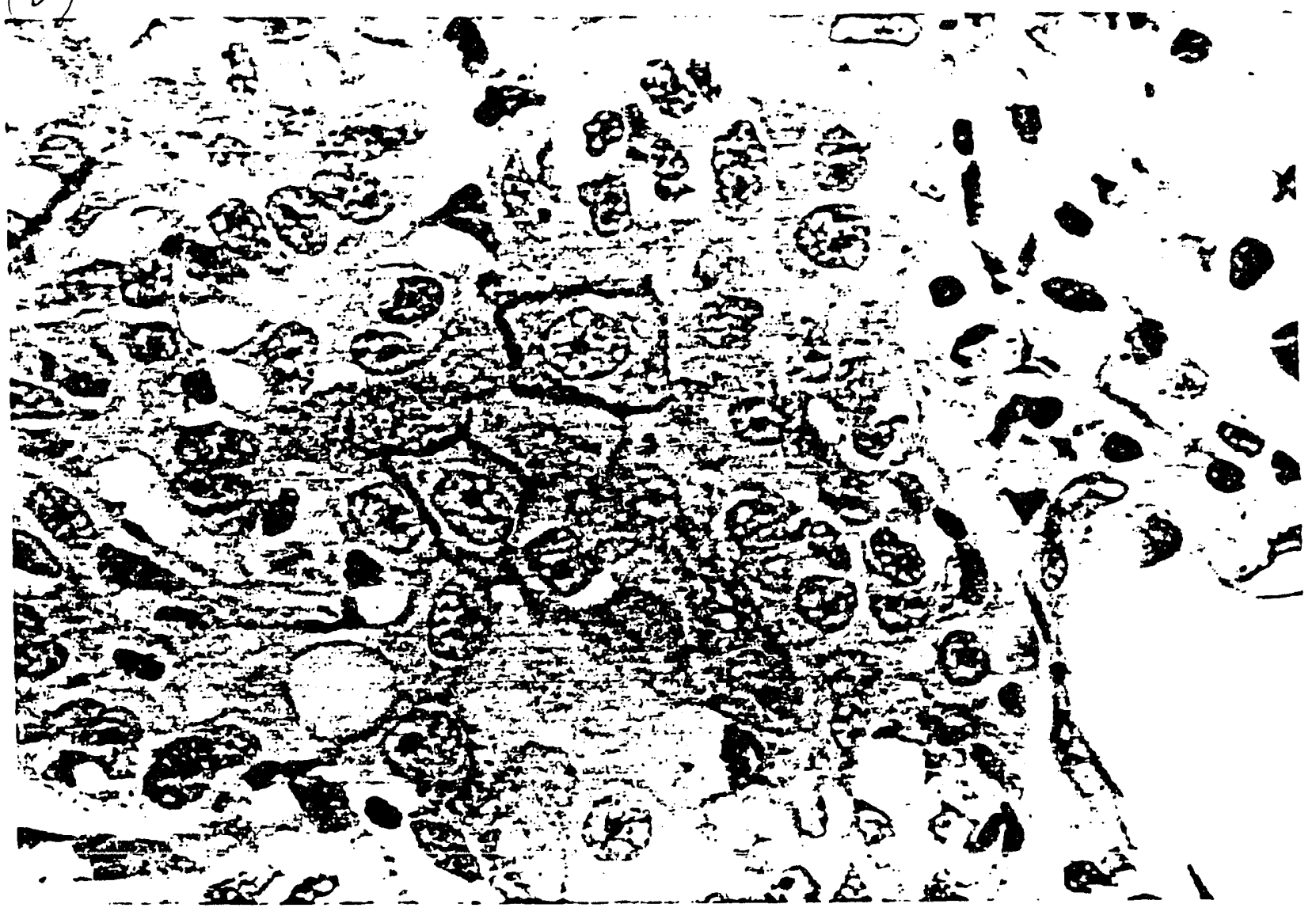




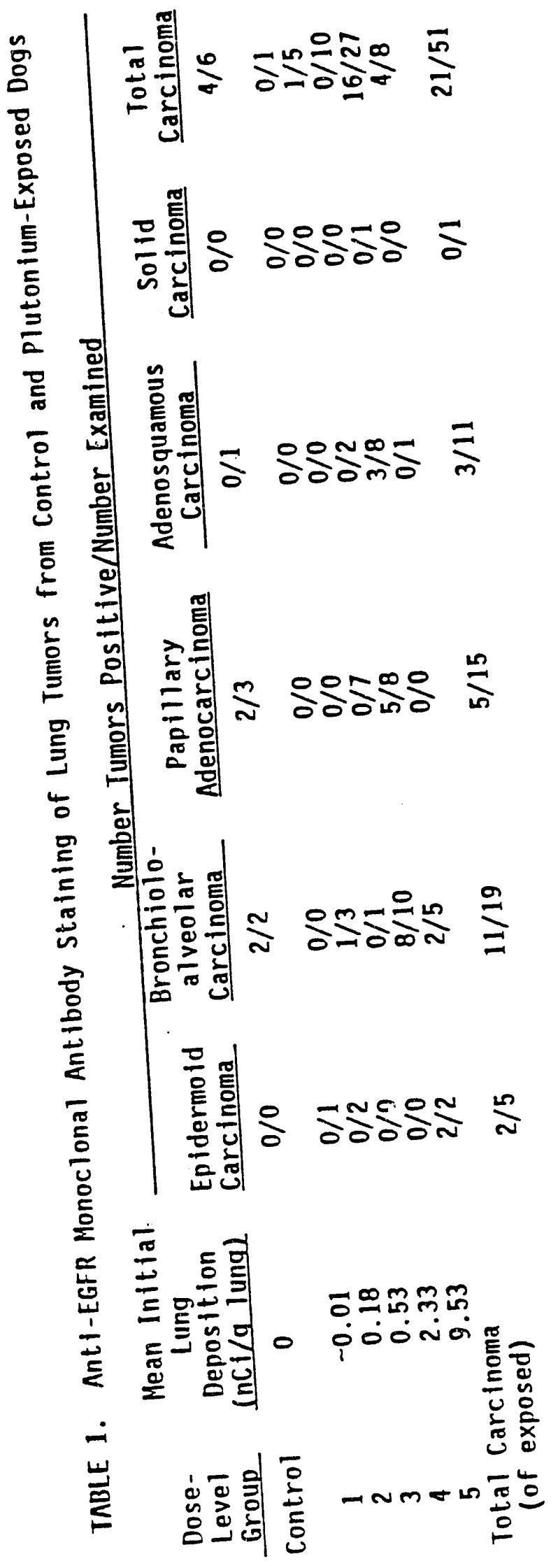


TABLE 2. Anti-EGFR Monoclonal Antibody Staining of Lung Tumors from Control and Plutonium-Exposed Dogs with Multiple Tumors

\begin{tabular}{|c|c|c|c|c|c|c|c|}
\hline \multirow{2}{*}{$\begin{array}{l}\text { Dose- } \\
\text { Level } \\
\text { Group } \\
\end{array}$} & \multirow[b]{2}{*}{$\begin{array}{l}\text { Dog } \\
\text { No. }\end{array}$} & \multicolumn{6}{|c|}{ Number of Tumors Positive/Number Examined } \\
\hline & & $\begin{array}{l}\text { Epi- } \\
\text { dermoid }\end{array}$ & $\begin{array}{l}\text { Bronchiolo- } \\
\text { alveolar }\end{array}$ & $\begin{array}{l}\text { Adeno- } \\
\text { carcinoma }\end{array}$ & $\begin{array}{l}\text { Adenosquamous } \\
\text { Carcinoma } \\
\end{array}$ & $\begin{array}{c}\text { Solid } \\
\text { Careinoma }\end{array}$ & Total \\
\hline $\begin{array}{l}0 \\
2 \\
3 \\
3 \\
4 \\
4 \\
4 \\
4 \\
4 \\
4 \\
5\end{array}$ & $\begin{array}{r}1005 \\
877 \\
771 \\
797 \\
777 \\
805 \\
808 \\
819 \\
839 \\
997 \\
796\end{array}$ & $0 / 2$ & $\begin{array}{l}4 / 4 \\
1 / 1 \\
1 / 1\end{array}$ & $\begin{array}{l}0 / 4 \\
1 / 1 \\
0 / 1 \\
0 / 1 \\
1 / 1 \\
1 / 1\end{array}$ & $\begin{array}{l}0 / 2 \\
1 / 1 \\
0 / 1 \\
0 / 2\end{array}$ & $0 / 1$ & $\begin{array}{l}2 / 2 \\
0 / 2 \\
0 / 2 \\
0 / 4 \\
6 / 6 \\
0 / 2 \\
0 / 2 \\
2 / 2 \\
2 / 2 \\
0 / 2 \\
2 / 2\end{array}$ \\
\hline & Total & $2 / 4$ & $6 / 6$ & $5 / 11$ & $1 / 6$ & $0 / 1$ & $14 / 28$ \\
\hline
\end{tabular}


TABLE 3. Anti-EGFR Staining in Littermates with Lung Tumors

\begin{tabular}{cc}
$\begin{array}{c}\text { Litter } \\
\text { No. }\end{array}$ & $\begin{array}{c}\text { Number of Dogs Positive/ } \\
\text { Number Examined }\end{array}$ \\
\cline { 2 - 2 } 100 & $2 / 2$ \\
101 & $2 / 2$ \\
115 & $2 / 2$ \\
118 & $2 / 2$ \\
105 & $0 / 2$ \\
109 & $0 / 4$ \\
102 & $0 / 2$ \\
104 & $0 / 2$ \\
119 & $0 / 2$ \\
125 & $0 / 2$ \\
108 & $2 / 3$
\end{tabular}


TABLE 4. Anti-EGFR Staining of Spontaneous Dog Lung Tumors and Lung Tumors from Plutonium-Exposed Dogs

Number of Tumor Postive/Number Examined

\begin{tabular}{|c|c|c|c|c|c|c|}
\hline Groups & $\begin{array}{l}\text { Epidermoid } \\
\text { Carcinoma } \\
\end{array}$ & $\begin{array}{l}\text { Bronchiolo- } \\
\text { alveolar } \\
\text { Carcinoma } \\
\end{array}$ & $\begin{array}{l}\text { Adeno- } \\
\text { carcinoma }\end{array}$ & $\begin{array}{l}\text { Adenosquamous } \\
\text { Carcinoma }\end{array}$ & $\begin{array}{l}\text { Other } \\
\text { Tumor }\end{array}$ & Total \\
\hline $\begin{array}{l}\text { Spontaneous } \\
\text { control }\end{array}$ & $1 / 4$ & $6 / 10$ & $3 / 15$ & $2 / 3$ & $1 / 9$ & $13 / 41(32)^{a}$ \\
\hline $\begin{array}{c}\text { Experimental } \\
\text { control }\end{array}$ & $0 / 0$ & $2 / 2$ & $2 / 3$ & $0 / 1$ & $0 / 0$ & $4 / 6(67)$ \\
\hline $\begin{array}{l}\text { Combined } \\
\text { control }\end{array}$ & $1 / 4(25)$ & $8 / 12(67)$ & $5 / 18(28)$ & $2 / 4(50)$ & $1 / 9$ & $17 / 47(36)$ \\
\hline Pu-exposed & $2 / 5(40)$ & $11 / 19(58)$ & $5 / 15(33)$ & $3 / 11(27)$ & $0 / 1$ & $21 / 51(41)$ \\
\hline
\end{tabular}

a Percent positive in parentheses. 

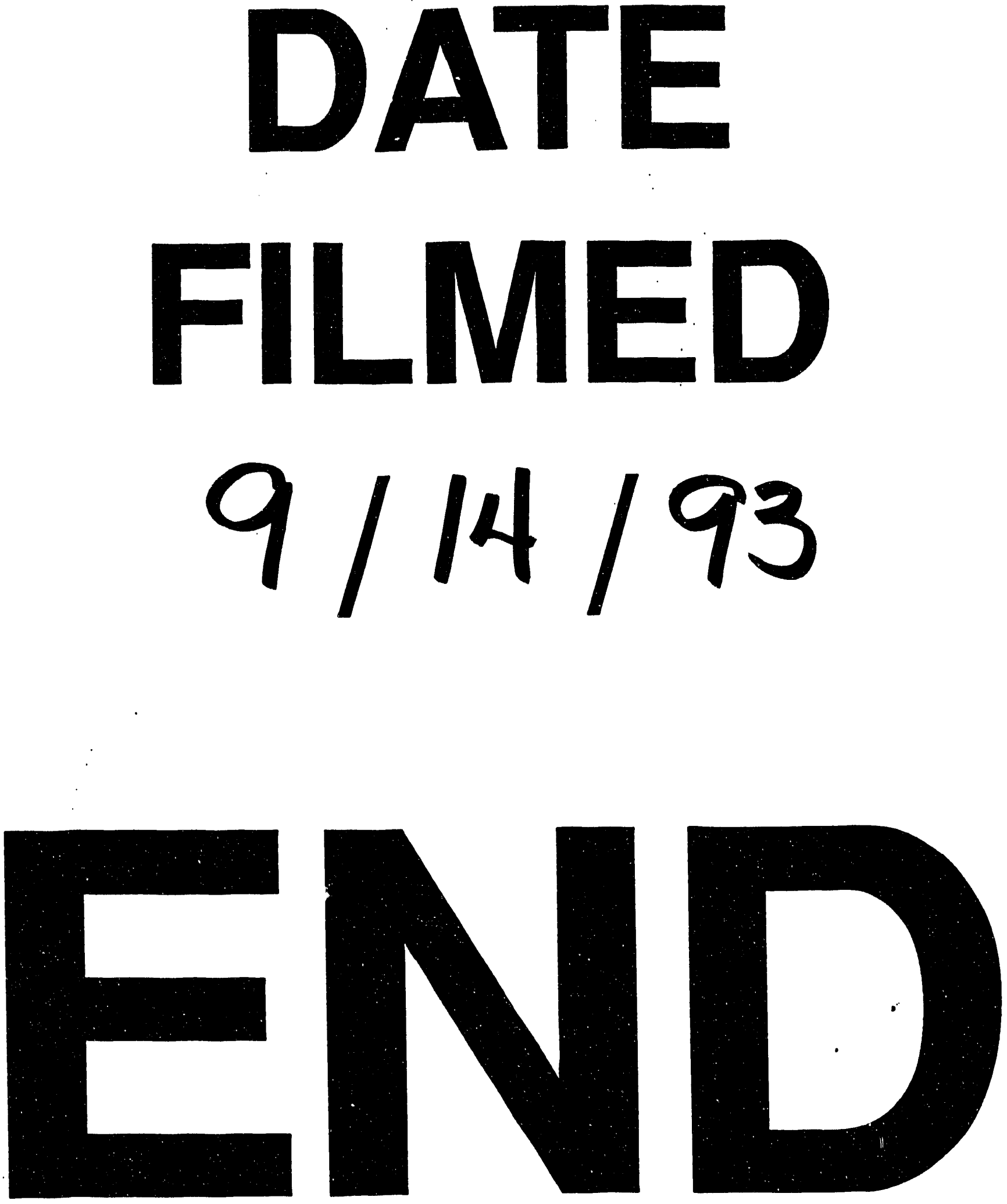
